\title{
SISTEM PENDUKUNG KEPUTUSAN PENJADWALAN PENGEMUDI DENGAN MENGGUNAKAN ALGORITMA ROUND ROBIN (STUDI KASUS: ZENA TRAVEL)
}

\author{
${ }^{1}$ Yogie Ariyanto $\mathrm{P},{ }^{2}$ Soetam Rizky Wicaksono \\ 12 Jurusan Sistem Informasi, Fakultas Sains dan Teknologi \\ Universitas Ma Chung, Jl. Villa Puncak Tidar N-01, Malang 65651 \\ Telp. (0341) 550171; Fax. (0341) 550175 \\ e-mail: yogieariyanto@gmail.com , soetam.rizky@machung.ac.id
}

\begin{abstract}
Abstrak
Penjadwalan merupakan aspek umum dalam suatu perusahaan travel. Dalam proses bisnisnya selain pengaturan reservasi pelanggan, pengaturan jadwal beban kerja pada pengemudi juga merupakan faktor yang penting. Pada travel komuter (dalam kasus ini dengan jadwal rutin harian) yang masih mengadaptasi sistem penjadwalan manual, akan menimbulkan masalah pada saat pembagian jadwal pengemudi sering tidak berimbang. Hal ini akan mengakibatkan beban kerja dan gaji setiap pengemudi juga tidak imbang. Selain itu, sering terjadi kesalahan dari operator dalam melakukan proses penjadwalan yang masih manual. Sehingga perlu dibuat solusi berupa sistem penjadwalan pengemudi dengan memanfaatkan algoritma round robin atau sering disebut RR. RR adalah algoritma yang dalam prosesnya dapat disela oleh proses lain dan tidak berprioritas karena adanya quantum. Hal ini tentu merupakan keunggulan RR dalam kriteria penjadwalan yaitu fairness. Hasil ujicoba algoritma RR telah terbukti meningkatkan efisiensi dalam proses penjadwalan dan dapat dihandalkan sebagai solusi untuk meingkatkan kinerja operator serta sesuai dengan kriteria penjadwlan yaitu fairness.
\end{abstract}

Kata Kunci: sistem penjadwalan driver, round robin, sistem informasi, Travel

\begin{abstract}
Schedulling is the common aspect of Travel Company. In business process, beside customer reservation, setting scheduling to job rate of the driver is an important factor in a travel company. For some travel companies that still use manual system, There is problem like driver plotting become unfair. This problem will cause job rate and salary of the driver become unfair too. Otherwise, it is oftenly making human error mistake for the operator to do their job by using manual system. Based on these problems, a driver scheduling system can be optimized using round robin algorithm or so called RR. RR is the algorithm that the process can be interrupted by another process and is not prioritized because of the quantum. It is certainly an advantage in the $R R$ scheduling fairness criteria. RR algorithm on test results has proven to increase efficiency in the process of scheduling and reliable as a solution to boost the performance of the operator and also in accordance with the fairness criteria of scheculling.
\end{abstract}

Keywords: scheduling system for drivers, round robin, information system, Travel

\section{PENDAHULUAN}

Zena Travel merupakan perusahaan jasa transportasi yang dibentuk oleh P.O Zena. Zena travel berlokasi di Kecamatan Buring, Kota Malang. Jasa transportasi Zena ini dibentuk untuk mengambil peluang menggaet penumpang yang bertujuan ke Bandara Juanda karena tidak dimungkinkan bagi P.O untuk mengambil alih penumpang yang bertujuan ke Bandara Juanda secara langsung.

Zena travel telah memiliki 77 agen untuk area kota Malang. Saat ini, Zena Travel melakukan ekspansi, sehingga ada beberapa perusahaan yang cukup besar juga menjadi agen dari Zena travel. Namun dalam bisnisnya, sistem manual yang masih diadaptasikan oleh Zena Travel perlahan menjadi masalah yang perlu diwaspadai. 
Pengaturan jadwal pengemudi yang masih manual mengakibatkan operator kesulitan hingga menimbulkan human error serta sering tidak adil dalam menentukan plotting jadwal yang sesuai karena jumlah armada dan pengemudi yang tidak seimbang. Selain itu, jika pengemudi berhalangan hadir, penjadwalan manual jelas tidak efisien karena operator harus membuat jadwal dari awal dengan mengecek parameter satu per satu. Penjadwalan manual mengakibatkan beban kerja pengemudi dan gaji tidak seimbang.

Berdasarkan permasalahan tersebut, maka dapat disimpulkan bahwa Zena Travel membutuhkan suatu sistem penjadwalan pengemudi yang lebih efektif dan tepat guna untuk dapat membantu pihak Travel dalam menentukan jadwal dengan parameter yang sesuai sehingga beban kerja, libur dan gaji pengemudi seimbang. Algoritma Round Robin dapat dimanfaatkan untuk optimasi sistem karena algoritma ini sesuai dengan kriteria penjadwalan yang cepat, fair dan efisien (Monica \& Hansen, 2014; Triono, 2015; Nieh, Vaill, \& Zhong, 2001).

Dengan dibuatnya sistem penjadwalan pengemudi dengan menggunakan algoritma yang tepat, diharapkan akan mampu membantu Zena Travel dalam mengatur jadwal dengan lebih cepat dan akurat tanpa terjadi bentrok jadwal berdasarkan parameter yang terkait. Selain itu diharapkan sistem penjadwalan pengemudi dapat membantu operator untuk mengoptimalkan kinerjanya.

\section{METODE PENELITIAN}

Sebagai dasar untuk dibangunnya suatu Sistem Pendukung Keputusan Penjadwalan driver dengan algoritma round robin, penulis menggunakan metode wawancara pada narasumber dari zena travel sendiri, yaitu langsung kepada manager zena travel. Wawancara dilakukan untuk mengetahui kebutuhan sistem serta proses bisnis yang ada pada zena travel khususnya yang terkait dan berhubungan langsung dalam pembuatan jadwal pengemudi, gaji dan reservasi customer.

Sedangkan metodologi yang digunakan untuk pengembangan sistem mengacu pada teori pengembangan SDLC (System Development Life Cycle).Tahapan yang dilakukan pada proses SDLC adalah (Kendall, 2011; Jogiyanto, 2009): (1) Identifying Problems, Opportunities, and Objectives, (2) Determining Human Information Requirements, (3) Analyzing System Needs, (4)Designing the Recommended System,(5) Developing and Documenting Software, (6) Testing and Maintaining the System, dan (7) Implementing and Evaluating the System. Fase pertama dan kedua telah dijelaskan dalam pendahuluan, sedangkan fase ketiga dan keempat akan dijelaskan pada bab ini. Fase kelima sampai ketujuh akan dibahas pada bab berikutnya. Fase perancangan didokumentasikan dengan menggunakan Data Flow Diagram (DFD), Workflow dan Entity Relation Diagram (ERD)

\section{Sistem Pendukung Keputusan (SPK)}

Sistem Pendukung Keputusan adalah bagian dari sistem informasi berbasis komputer yang termasuk dalam sistem berbasis pengetahuan yang digunakan untuk mendukung pengambilan keputusan dalam suatu organisasi atau perusahaan, dan sebagai pengolah data menjadi informasi untuk mengambil suatu keputusan dari masalah yang semi terstruktur yang spesifik (Kusrini, 2007; Goswami \& Barua, 2008).

SPK biasanya dibangun untuk mendukung solusi atas suatu masalah atau mengevaluasi peluang. SPK yang seperti itu disebut Aplikasi SPK yang digunakan untuk mengambil keputusan. SPK lebih ditujukan untuk mendukung manajemen dalam melakukan perkerjaan yang bersifat analitis dalam situasi yang kurang terstruktur dan dengan kriteria yang kurang jelas (Kusrini, 2007). SPK tidak dimaksudkan untuk mengoptimasikan pengambilan keputusan, tetapi memberikan perangkat interaktif yang memungkinkan pengambil keputusan untuk melakukan berbagai analisa menggunakan model-model yang tersedia.

Beberapa karakteristik yang dimiliki oleh SPK, antara lain (Kusrini, 2007; Perraju, 2013; Druzdzel \& Flynn, 2010) : (a) mengontrol tahapan dalam pembuatan keputusan, (b) mendukung banyak proses dan gaya pengambilan keputusan, (c) menyediakan dukungan terhadap keputusan 
yang berlanjut, serta (d) meningkatkan efektifitas pembuatan sistem dalam hal waktu dan kualitas.

\section{Algoritma Round Robin}

Algoritma Round Robin adalah sebuah algoritma yang paling tua, sederhana, fair dan luas, Algoritma ini mempunyai dasar menggunakan quantum (Hartomo, 2005; Rajput \& Gupta, 2012; Nieh, Vaill, \& Zhong, 2001). Algoritma Round Robin merupakan penjadwalan Preemptive, terutama oleh penjadwal berdasarkan lama berjalannya proses, yang disebut preempt by time (Datta, 2015; Rasmussen \& Trick, 2008).

Penggunaan $\mathrm{RR}$ di dalam proses penjadwalan di dunia nyata (bukan untuk proses CPU) telah banyak dilakukan secara empiris oleh peneliti terdahulu. Sebagai contoh adalah proses penjadwalan untuk pengiriman barang (Monica \& Hansen, 2014), pendaftaran siswa baru (Triono, 2015), dan penjadwalan secara real time (Datta, 2015). Sehingga, penggunaan RR untuk penjadwalan memang telah terbukti dapat digunakan secara efektif di beberapa kasus yang memang membutuhkan pengaturan tersebut.

Disamping itu juga merupakan penjadwalan tanpa prioritas. Dengan menganalisa kriteria penilaian penjadwalan, maka: (a) berdasarkan Fairness, maka penjadwalan $R R$ adil, bila dipandang dari persamaan pelayanan oleh pemroses, (b) berdasarkan efisiensi, maka penjadwalan $\mathrm{RR}$ cenderung efisien pada sistem interaktif, (c) berdasarkan waktu tanggap, maka penjadwalan RR memuaskan untuk sistem interaktif, tidak memadai untuk sistem waktu nyata, (d) berdasarkan Turn Arround Time, maka penjadwalan $R R$ cukup bagus, serta (e) berdasarkan Throughtput, maka penjadwalan RR cukup bagus.

Pada dasarnya algoritma ini mirip dengan FIFO, hanya bersifat Preemptive dan didalamnya digunakan Quantum time untuk membatasi waktu proses. Formula yang digunakan untuk menghitung waktu tunggu rata-rata dalam algoritma Round Robin .

$\lambda=\sum \mathrm{W} / \mathrm{n}$

Keterangan:

$\lambda=$ waktu tunggu rata-rata

$\mathrm{W}=$ waktu tunggu tiap proses

$\mathrm{n}=$ jumlah proses antrian

\section{HASIL DAN PEMBAHASAN}

Halaman Plotting armada digunakan untuk mengatur armada dan Pengemudi yang mengemudikan armada tersebut. Halaman plotting armada dapat dilihat pada gambar 3.3.

Halaman transaksi penjadwalan digunakan untuk mengatur jadwal secara otomatis dengan memanfaatkan algoritma RR sesuai parameter yang telah didapat. Input yang diperlukan adalah nilai quantum, tanggal awal dan tanggal akhir pada form penjadwalan yang dapat dilihat pada gambar 1, Selanjutnya klik button generate untuk menuju ke form jadwal yaitu hasil dari eksekusi program pada form penjadwalan yang dapat dilihat pada gambar 2 . 


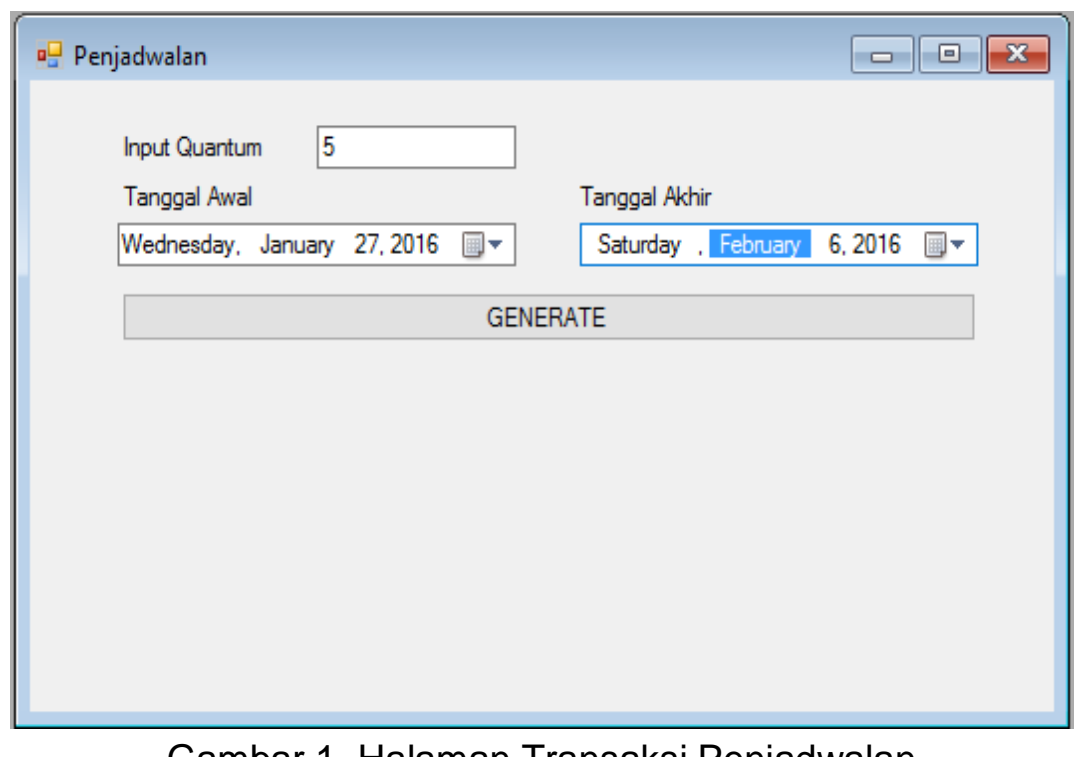

Gambar 1. Halaman Transaksi Penjadwalan

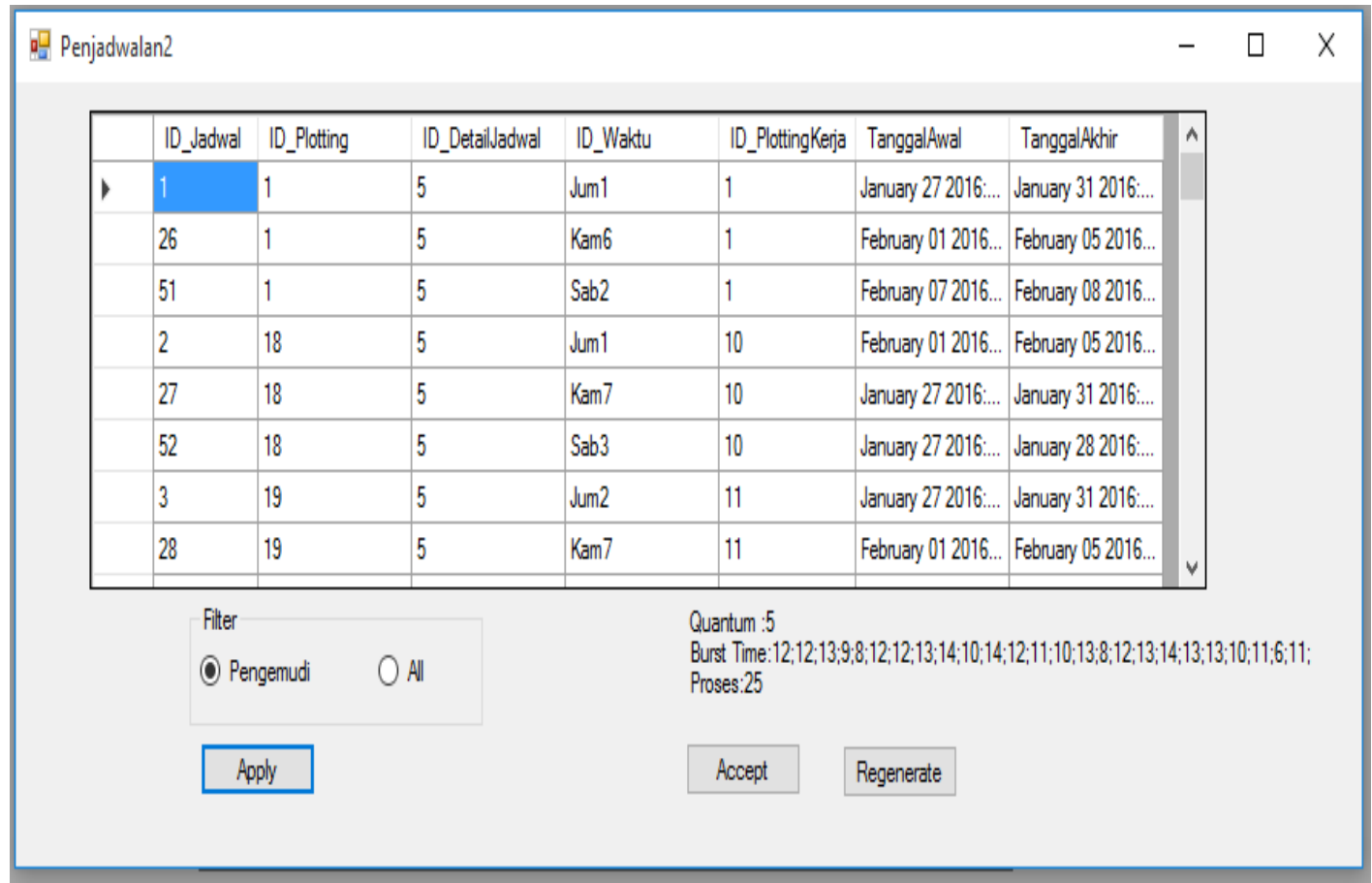

Gambar 2. Halaman Transaksi Penjadwalan

\section{Uji Coba Algoritma RR}

Tujuan dari uji coba penghitungan ini adalah untuk dilakukan analisa terhadap proses penjadwalan untuk mengetahui performa dari algoritma round robin. Uji coba akan dilakukan dengan cara membuat plotting kerja pengemudi sama dengan nilai quantum yang bervariasi. Kemudian membuat plotting kerja pengemudi bervariasi dan besar nilai quantum yang bervariasi pula. Dengan analisa ini akan diketahui kriteria fairness algoritma dalam pembagian proses yang masuk. 
- Beban kerja rata yaitu 6 dan quantum bernilai 6

\begin{tabular}{|l|l|l|l|l|l|l|}
\hline & Pengemudi & ID_Jadwal & ID_Plotting & ID_PlottingKeja & TanggalAwal & Tanggal/kkhir \\
\hline 1 & Eko & 1 & 1 & 1 & January 24 2016:03.00 & January 29 2016:03.00 \\
\hline 2 & Sol & 2 & 10 & 2 & January 30 2016:03.00 & February 04 2016:03.00 \\
\hline 3 & Jum & 3 & 11 & 3 & January 24 2016:05.00 & January 29 2016:05.00 \\
\hline 4 & Jos & 4 & 12 & 4 & January 30 2016:05.00 & February 04 2016:05.00 \\
\hline 5 & Trisnadi & 5 & 14 & 5 & January 24 2016:07.00 & January 29 2016:07.00 \\
\hline 6 & Zainul & 6 & 15 & 6 & January 30 2016:07.00 & February 04 2016:07.00 \\
\hline 7 & Joko & 7 & 16 & 7 & January 24 2016:09.00 & January 29 2016:09.00 \\
\hline 8 & KOdir & 8 & 18 & 8 & January 30 2016:09.00 & February 04 2016:09.00 \\
\hline 9 & Aiff & 9 & 19 & 9 & January 24 2016:11.00 & January 29 2016:11.00 \\
\hline 10 & Wiyono & 10 & 22 & 10 & January 30 2016:11.00 & February 04 2016:11.00 \\
\hline
\end{tabular}

Gambar 3. Beban kerja dan Quantum sama

Pada gambar 3 beban kerja setiap pengemudi di plotting rata dengan nilai yang sama yaitu 6 dengan nilai quantum 6. Maka dihasilkan rentang kerja setiap pengemudi adalah 6 hari kerja dilihat dari tanggal awal dan tanggal akhir.

- Beban kerja rata yaitu 6 dan quantum lebih besar bernilai 7

\begin{tabular}{|l|l|l|l|l|l|l|}
\hline & Pengemudi & ID_Jadwal & ID_Plotting & ID_Plottingkeja & TanggalAwal & TangalAkhir \\
\hline 1 & Eko & 1 & 1 & 1 & January 24 2016:03.00 & January 29 2016:03.00 \\
\hline 2 & Sol & 2 & 10 & 2 & January 30 2016:03.00 & February 04 2016:03.00 \\
\hline 3 & Jum & 3 & 11 & 3 & January 24 2016:05.00 & January 29 2016:05.00 \\
\hline 4 & Jos & 4 & 12 & 4 & January 30 2016:05.00 & February 04 2016:05.00 \\
\hline 5 & Trisnadi & 5 & 14 & 5 & January 24 2016:07.00 & January 29 2016:07.00 \\
\hline 6 & Zainul & 6 & 15 & 6 & January 30 2016:07.00 & February 04 2016:07.00 \\
\hline 7 & Joko & 7 & 16 & 7 & January 24 2016:09.00 & January 29 2016:09.00 \\
\hline 8 & KOdir & 8 & 18 & 8 & January 30 2016:09.00 & February 04 2016:09.00 \\
\hline 9 & Aif & 9 & 19 & 9 & January 24 2016:11.00 & January 29 2016:11.00 \\
\hline 10 & Wiyono & 10 & 22 & 10 & January 30 2016:11.00 & February 04 2016:11.00 \\
\hline
\end{tabular}

Gambar 4. Quantum lebih besar dari beban kerja

Pada gambar 4 beban kerja setiap pengemudi diplotting rata dengan nilai yang sama yaitu 6 dengan nilai quantum 7. Maka hasilnya akan sama dengan nilai quantum yang sama karena quantum lebih besar dari nilai beban kerja sehingga proses yang masuk dieksekusi habis. 
- Beban kerja rata yaitu 6 dan quantum lebih kecil bernilai 3

\begin{tabular}{|l|l|l|l|l|l|l|}
\hline & Pengemudi & ID_Jadwal & ID_Plotting & ID_PlottingKerja & TanggalAwal & TanggalAkhir \\
\hline 1 & Eko & 1 & 1 & 1 & January 24 2016:03.00 & January 26 2016:03.00 \\
\hline 2 & Sol & 2 & 10 & 2 & January 27 2016:03.00 & January 29 2016:03.00 \\
\hline 3 & Jum & 3 & 11 & 3 & January 30 2016:03.00 & February 01 2016:03.00 \\
\hline 4 & Jos & 4 & 12 & 4 & February 02 2016:03.00 & February 04 2016:03.00 \\
\hline 5 & Trisnadi & 5 & 14 & 5 & January 24 2016:05.00 & January 26 2016:05.00 \\
\hline 6 & Zainul & 6 & 15 & 6 & January 27 2016:05.00 & January 29 2016:05.00 \\
\hline 7 & Joko & 7 & 16 & 7 & January 30 2016:05.00 & February 01 2016:05.00 \\
\hline 8 & KOdir & 8 & 18 & 8 & February 02 2016:05.00 & February 04 2016:05.00 \\
\hline 9 & Arif & 9 & 19 & 9 & January 24 2016:07.00 & January 26 2016:07.00 \\
\hline 10 & Wiyono & 10 & 22 & 10 & January 27 2016:07.00 & January 29 2016:07.00 \\
\hline 11 & Eko & 11 & 1 & 1 & January 30 2016:07.00 & February 01 2016:07.00 \\
\hline 12 & Sol & 12 & 10 & 2 & February 02 2016:07.00 & February 04 2016:07.00 \\
\hline 13 & Jum & 13 & 11 & 3 & January 24 2016:09.00 & January 26 2016:09.00 \\
\hline 14 & Jos & 14 & 12 & 4 & January 27 2016:09.00 & January 29 2016:09.00 \\
\hline 15 & Trisnadi & 15 & 14 & 5 & January 30 2016:09.00 & February 01 2016:09.00 \\
\hline 16 & Zainul & 16 & 15 & 6 & February 02 2016:09.00 & February 04 2016:09.00 \\
\hline 17 & Joko & 17 & 16 & 7 & January 24 2016:11.00 & January 26 2016:11.00 \\
\hline 18 & KOdir & 18 & 18 & 8 & January 27 2016:11.00 & January 29 2016:11.00 \\
\hline 19 & Avif & 19 & 19 & 9 & January 30 2016:11.00 & February 01 2016:11.00 \\
\hline 20 & Wiyono & 20 & 22 & 10 & February 02 2016:11.00 & February 04 2016:11.00 \\
\hline
\end{tabular}

Gambar 5. Beban kerja lebih besar dari quantum

Pada gambar 5 beban kerja setiap pengemudi diplotting rata dengan nilai yang sama yaitu 6 dengan nilai quantum 3. Maka hasilnya proses yang masuk akan dikurangi sejumlah quantum untuk selanjutnya menunggu giliran hingga proses diekseskusi habis.
Rentang kerja terlihat pada tanggal awal dan tanggal akhir yaitu 3 hari.

- Beban Kerja Variatif dan quantum bernilai 3 (Studi kasus pengemudi kodir nilai quantum lebih kecil dari beban kerja) 


\begin{tabular}{|c|c|c|c|c|c|c|}
\hline & Pengemudi & Jumlah & ID_PlottingKerja & & & \\
\hline 1 & Eko & 3 & 1 & & & \\
\hline 2 & KOवाr & 7 & 10) & & & \\
\hline 3 & Sol & 9 & 2 & & & \\
\hline 4 & Jum & 8 & 3 & & & \\
\hline 5 & Jos & 7 & 4 & & & \\
\hline 6 & Jupri & 6 & 5 & & & \\
\hline \multirow[t]{4}{*}{7} & Trisnadi & 5 & 6 & & & \\
\hline & Pengemudi & ID_Jadwal & ID_Plotting & ID_PlottingKerja & TanggalAwal & TanggalAkhir \\
\hline & Rudi & 9 & 17 & 9 & January 24 2016:07.00 & January $262016: 07.00$ \\
\hline & KOdir & 10 & 18 & 10 & January 27 2016:07.00 & January 29 2016:07.00 \\
\hline 11 & Sol & 11 & 10 & 2 & January 30 2016:07.00 & February $012016: 07.00$ \\
\hline 12 & Jum & 12 & 11 & 3 & February 02 2016:07.00 & February 04 2016:07.00 \\
\hline 13 & Jos & 13 & 12 & 4 & January 24 2016:09.00 & January 26 2016:09.00 \\
\hline 14 & Jupri & 14 & 13 & 5 & January 27 2016:09.00 & January 29 2016:09.00 \\
\hline 15 & Trisnadi & 15 & 14 & 6 & January 30 2016:09.00 & January 31 2016:09.00 \\
\hline 16 & Zainul & 16 & 15 & 7 & February 01 2016:09.00 & February 01 2016:09.00 \\
\hline 17 & Joko & 17 & 16 & 8 & February 02 2016:09.00 & February 04 2016:09.00 \\
\hline 18 & Rudi & 18 & 17 & 9 & January 24 2016:11.00 & January 26 2016:11.00 \\
\hline 19 & KOdir & 19 & 18 & 10 & January 27 2016:11.00 & January 29 2016:11.00 \\
\hline 20 & Sol & 20 & 10 & 2 & January $302016: 11.00$ & February $012016: 11.00$ \\
\hline 21 & Jum & 21 & 11 & 3 & February 02 2016:11.00 & February 03 2016:11.00 \\
\hline 22 & Jos & 22 & 12 & 4 & February 04 2016:11.00 & February 04 2016:11.00 \\
\hline 23 & Joko & 23 & 16 & 8 & January 24 2016:15.00 & January 26 2016:15.00 \\
\hline 24 & KOdir & 24 & 18 & 10 & January 27 2016:15.00 & January 27 2016:15.00 \\
\hline 25 & Joko & 25 & 16 & 8 & January 28 2016:15.00 & January 28 2016:15.00 \\
\hline
\end{tabular}

Gambar 6. Studi Kasus beban kerja variatif dan quantum lebih kecil

Pada gambar 6 beban kerja setiap pengemudi diplotting variatif dengan nilai quantum 3. Maka hasilnya proses yang masuk akan dikurangi sejumlah quantum untuk selanjutnya menunggu giliran hingga proses diekseskusi habis. Pada pengemudi bernama Kodir dengan beban kerja 7 maka akan dieksekusi sebanyak tiga kali.

- Beban Kerja Variatif dan quantum bernilai 7 (Studi kasus pengemudi kodir nilai quantum sama dengan beban kerja)

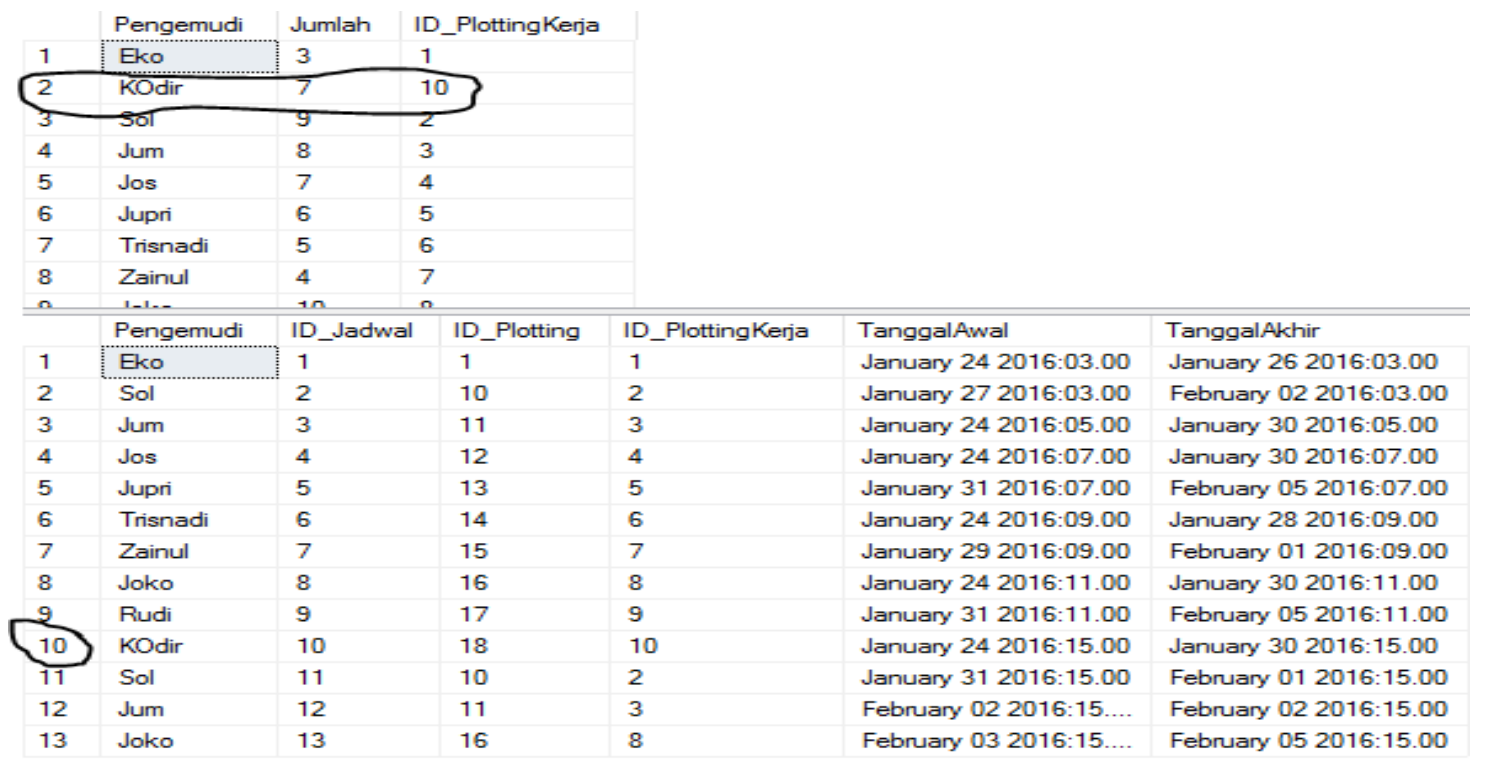

Gambar 7. Studi Kasus beban kerja dan Quantum sama 
Pada gambar 7 beban kerja setiap pengemudi di plotting variatif dengan nilai quantum 7. Maka hasilnya proses yang masuk akan dikurangi sejumlah quantum untuk selanjutnya menunggu giliran hingga proses diekseskusi habis. Pada pengemudi bernama Kodir dengan beban kerja 7 maka akan dieksekusi sekali karena jumlah beban kerja sama dengan nilai quantum.

- Beban Kerja Variatif dan quantum bernilai 9 (Uji coba pengemudi bernama Kodir beban kerja kurang dari nilai quantum dan pengemudi bernama Joko memiliki beban kerja yang lebih besar dari nilai quantum)

\begin{tabular}{|l|l|l|l|}
\hline & Pengemudi & Jumlah & ID_PlottingKerja \\
\hline 1 & Eko & 3 & 1 \\
\hline 2 & KOdir & 7 & 10 \\
\hline 3 & Sol & 9 & 2 \\
\hline 4 & Jum & 8 & 3 \\
5 & Jos & 7 & 4 \\
\hline 6 & Jupri & 6 & 5 \\
\hline 7 & Trisnadi & 5 & 6 \\
\hline 8 & Zainul & 4 & 7 \\
\hline 9 & Joko & 10 & 8 \\
\hline 10 & Rudi & 6 & 9 \\
\hline
\end{tabular}

\begin{tabular}{|l|l|l|l|l|l|l|}
\hline \hline & Pengemudi & ID_Jadwal & ID_Plotting & ID_PlottingKerja & TanggalAwal & TanggalAkhir \\
\hline 1 & Eko & 1 & 1 & 1 & January 24 2016:03.00 & January 26 2016:03.00 \\
\hline 2 & Sol & 2 & 10 & 2 & January 27 2016:03.00 & February 04 2016:03.00 \\
\hline 3 & Jum & 3 & 11 & 3 & January 24 2016:05.00 & January 31 2016:05.00 \\
\hline 4 & Jos & 4 & 12 & 4 & January 24 2016:07.00 & January 30 2016:07.00 \\
\hline 5 & Jupri & 5 & 13 & 5 & January 31 2016:07.00 & February 05 2016:07.00 \\
\hline 6 & Trisnadi & 6 & 14 & 6 & January 24 2016:09.00 & January 28 2016:09.00 \\
\hline 7 & Zainul & 7 & 15 & 7 & January 29 2016:09.00 & February 01 2016:09.00 \\
\hline 8 & Joko & 8 & 16 & 8 & January 24 2016:11.00 & February 01 2016:11.00 \\
\hline 9 & Rudi & 9 & 17 & 9 & January 24 2016:15.00 & January 29 2016:15.00 \\
\hline 10 & KOdir & 10 & 18 & 10 & January 30 2016:15.00 & February 05 2016:15.00 \\
\hline 11 & Joko & 11 & 16 & 8 & January 24 2016:17.00 & January 24 2016:17.00
\end{tabular}

Gambar 8. Beban kerja dan Quantum sama

Kesimpulan hasil uji coba adalah dengan nilai beban kerja yang jumlahnya sama dengan nilai quantum maka hasilnya akan sama dengan quantum yang jumlahnya melebihi beban kerja. Karena RR akan sama dengan algoritma FIFO jika quantum sama atau lebih besar dari beban kerja. Namun hal ini menjadi kelebihan RR karena dapat menghindari fairless terhadap proses yang memiliki beban kerja dibawah quantum. Jika nilai quantum lebih kecil maka proses akan digilir secara adil sesuai konsep dari RR.

Berdasarkan hasil uji coba yang dilakukan, nilai beban kerja yang diplotting secara variatif maka proses akan diproses sesuai dengan giliran yang masuk dan dikurangi dengan quantum. Maka dilihat pada hasil uji coba pengemudi bernama Kodir pada gambar 8 dengan nilai beban kerja yang lebih kecil dari quantum maka proses Kodir ketika masuk akan langsung dihabiskan. Berbeda dengan pengemudi bernama Joko karena nilai beban kerjanya 10 dengan quantum 9 maka pada saat pertama proses masuk akan diproses sesuai quantum untuk sisa 1 selanjutnya akan diproses kembali ketika gilirannya. 


\section{SIMPULAN}

Berdasarkan hasil dan pembahasan, maka dapat diambil beberapa kesimpulan bahwa Sistem Penjadwalan pengemudi pada studi kasus Zena Travel ini telah memenuhi tujuan yaitu: (1) sistem penjadwalan dapat membantu operator untuk memaksimalkan kinerjanya termasuk dalam pembuatan jadwal pengemudi, (2) sistem penjadwalan pengemudi dapat membantu Zena Travel untuk mendukung proses bisnis selain penjadwalan pengemudi juga dokumentasi customer dan reservasi, (3) sistem penjadwalan pengemudi dapat menghasilkan laporan jadwal yang fleksibel yaitu dapat diprint atau diexport berupa pdf sehingga paperless, serta (4) hasil ujicoba algoritma round robin telah terbukti meningkatkan efficiency pada proses penjadwalan dan telah memenuhi kriteria penjadwalan yaitu fairness.

Namun jika nilai quantum lebih dari atau sama dengan nilai beban kerja maka algoritma round robin akan sama dengan algoritma FIFO artinya akan mengeksekusi proses yang masuk lebih dulu. Namun hal ini menjadi kelebihan algoritma round robin karena dapat menghindari fairless terhadap proses yang memiliki beban kerja dibawah quantum (Rasmussen \& Trick, 2008).

Saran untuk pengembangan lebih jauh dari Sistem Penjadwalan Pengemudi ini diantaranya: (1) dilengkapi reservasi online untuk kemudahan customer, serta (2) dilengkapi dengan tambahan fitur sms broadcast sebagai notifikasi kepada customer.

\section{DAFTAR PUSTAKA}

Datta, L. (2015). Efficient Round Robin Scheduling Algorithm with Dynamic Time. I.J. Education and Management Engineering, 10-19.
Druzdzel, M. J., \& Flynn, R. R. (2010). Decision Support Systems. In M. J. Bates, \& M. N. Maack, Encyclopedia of Library and Information Sciences Third Edition (pp. 1-9). Taylor Francis. doi:10.1081/E-ELIS3120043887

Goswami, R., \& Barua, P. (2008). WebBased Decision Support System : Concept and Issues. In D. Laha, \& P. Mandal, Handbook of Computational Intelligence in Manufacturing and Production Management (pp. 300-313). IGI Global. doi:10.4018/978-159904-582-5

Hartomo, D. (2005). Sistem Operasi. Yogyakarta: Graha IImu.

Jogiyanto. (2009). Sistem Teknologi Informasi. 3 ed. Yogyakarta: ANDI.

Kendall, K. (2011). System Analysis and Design. 8th ed. New Jersey: Pearson Education.

Kusrini. (2007). Konsep dan Aplikasi Sistem Pendukung Keputusan. Yogyakarta: ANDI.

Monica, S., \& Hansen, S. (2014, Desember). Implementasi Algoritma Short Job First dan Round Robin pada Sistem Penjadwalan Pengiriman Barang. ULTIMATICS, VI(2), 94-99. Retrieved from http://library.umn.ac.id/jurnal/pu blic/uploads/papers/pdf/3ae310 9872e51407830483c2f558b76c. pdf

Nieh, J., Vaill, C., \& Zhong, H. (2001). Virtual-Time Round-Robin: An O(1) Proportional Share Scheduler. Proceesing 2001 USENIX Annual Technical Conference. Boston: USENIX.

Perraju, T. (2013, April). Artificial Intelligence And Decision Support Systems. International Journal of Advanced Research in IT and Engineering, 2(4), 1726.

Rajput, I. S., \& Gupta, D. (2012, October). A Priority based 
Round Robin CPU Scheduling Algorithm for Real Time Systems. International Journal of Innovations in Engineering and Technology (IJIET), 1(3), 111.

Rasmussen, R. V., \& Trick, M. A. (2008). Round robin scheduling - a survey. European Journal of Operational Research, 617-636.

Triono, G. (2015). Implementasi Load Balancing dengan menggunakan Algoritma Round Robin pada Kasus Pendaftaran Siswa Baru Sekolah Menengah Pertama Labschool UNESA Surabaya. iDeaTech (pp. 169176). Surabaya: iSTTS. Retrieved from http://ideatech.stts.edu/proceedi ng2015/169\%20-

\%20Gaguk\%20Triono.pdf 